\title{
Clinical problems related to the use of drugs in malnutrition
}

\author{
By Elizabeth M. E. Poskitt, Children's Hospital, Ladywood Middleway, \\ Birmingham BI6 8ET
}

It may not be immediately apparent why drugs need to be used in malnutrition. A good diet should be all that is necessary. However, clinical malnutrition may be precipitated by infection (Poskitt, 1972) and complicated by anaemia and cardiac failure (Wharton, Howells \& McCance, 1967). Where clinical malnutrition is common, children attending hospital or rural clinics for other conditions are likely to be poorly nourished. Yet little is known of drug metabolism in these or in the overtly malnourished child.

Adaptation of the body to low energy and protein intake involves profound biochemical changes. Where energy intake is deficient, body proteins are broken down to provide energy. Where protein is deficient, nitrogen is conserved by increased recycling of amino acids and decreased urea formation (Waterlow, r 968). $\mathrm{N}$ balance may be achieved, but is easily upset by infection, and could be upset by drugs that antagonize protein synthesis.

\section{Effects of drugs on absorption}

Diminished drug absorption. Kwashiorkor is associated with villous atrophy of the jejunal mucosa (Brunser, Reid, Monckeberg, Maccioni \& Contreras, I 968). Despite this, most nutrients, and probably drugs as well, are adequately absorbed. Yet absorption may be affected by substances routinely or frequently given together in malnutrition. Milk is the basic dietary treatment for kwashiorkor in most centres. Ferrous sulphate is often given too. This is poorly absorbed with a milk diet. Further, ferrous sulphate chelates with tetracycline in the gut, reducing absorption of this useful antibiotic (Neuvonen, Gothoni, Hackman \& af Bjorksten, 1970). Large doses of tetracycline inhibit iron absorption in rats by interfering with protein synthesis in the gut wall (Greenberger, 1973), an effect which may also be applicable to man. Fever causes decreased absorption of $\mathrm{Fe}$, and poorly nourished children are often febrile from associated infection (Beresford, Neale \& Brooks, 1971).

Effects of drugs on nutrient absorption. Underweight Italian children on a diet deficient in protein and energy, when treated with small doses of chlortetracycline, showed significant weight gain when compared with an untreated group on the same diet (Jolliffe, Frontali, Maggioni, Corbo \& Lanciano, 1956). Poor nutrition is associated with high bacterial counts in the jejunum (Mata, Mejicanos \& Jiménez, 1972). Chlortetracycline may have reduced the jejunal bacterial population and 
improved absorption since it will produce weight gain in blind-loop syndromes (Bayes \& Hamilton, I969). Bacteria in the small intestine deconjugate bile salts and cause malabsorption. However, the nonabsorbed antibiotic neomycin may give rise to a severe malabsorption syndrome, despite sterilizing the gut, through alteration of protein synthesis in the mucosal cells (Jacobsen, Chodos \& Faloon, r960).

\section{Effects of drugs on protein synthesis}

Although little used in paediatrics in the UK, tetracyclines and chloramphenicol are useful antibiotics in developing countries, since they are cheap and readily available and have broad-spectrum activity. They are effective through inhibition of ribosomal protein synthesis in bacteria, but can affect protein synthesis in man.

Tetracycline. Tetracyclines increase serum non-protein $\mathrm{N}$ and urinary amino acids and urea, without an increase in creatinine or uric acid excretion. This seems an 'anti-anabolic' effect rather than a catabolic effect (Berman \& Weinstein, 1971). In doses of more than $50 \mathrm{mg} / \mathrm{kg}$ body-weight per $\mathrm{d}$ (within the therapeutic range) bone growth in young children is inhibited. In premature infants tetracyclines can retard bone growth by $40 \%$ (Cohlan, Bevelander \& Tiamsic, 1963 ).

Chloramphenicol. Drugs such as phenytoin and tolbutamide, given with chloramphenicol, have increased activity owing to inhibition of synthesis of liver detoxicating enzymes. Other protein anabolic processes are probably affected, particularly where protein synthesis is rapid (Weisberger, 1968 ).

Haemoglobin synthesis is altered, causing failure of incorporation of $\mathrm{Fe}$ into the erythrocyte and development of apparent Fe-deficiency anaemia (Beck, 1970). Thus, both these antibiotics have disadvantages, since diminished protein synthesis, loss of $\mathrm{N}$ through increased urea formation, inhibition of growth and progressive anaemia are of no advantage to a child who must adapt to an inadequate diet, or who needs to grow rapidly following malnutrition.

\section{Studies of altered drug metabolism in kwashiorkor}

Chloroquine. Children with kwashiorkor excrete a higher ratio of chloroquine to its liver-formed metabolites before treatment than during recovery. However, the effect seems insufficient to require alteration of the usual antimalarial dose in malnutrition (Wharton \& McChesney, 1970).

Tetrachloroethylene. Of hospital admissions for kwashiorkor in Kampala, 40\% have hookworm infestation. Tetrachloroethylene, used to treat this, causes no detectable deterioration in liver function in these children, despite potential hepatotoxicity. Deficiency of amino acids and reduced sulphydryl groups might make the malnourished liver more susceptible to injury by drugs, but depressed liver microsomal activity slows the conversion of some drugs, perhaps tetrachloroethylene, to toxic metabolites. This could effectively protect the malnourished liver (Balmer, Howells \& Wharton, 1970).

Trimethoprim. In Uganda, about 10\% of hospital admissions with kwashiorkor have evidence of folate deficiency (Dean, 1965). Many drugs affect folate metabolism. 
Some, such as phenytoin, modify absorption from the gut. Others inhibit dihydrofolate reductase, the enzyme that converts dihydrofolate to tetrahydrofolate. Trimethoprim is an antibacterial drug that inhibits dihydrofolate reductase, but to a greater extent in bacteria than in man. In combination with the sulphonamide sulphamethoxazole, which inhibits the formation of $p$-aminobenzoic acid, trimethoprim has become a useful antibacterial agent. Nevertheless, trimethoprim can produce biochemical and clinical folate deficiency (Lancet, 1973).

With impaired reduction of dihydrofolate to tetrahydrofolate, histidine is incompletely metabolized and formiminoglutamic acid (FIGlu) is excreted in the urine. Children with kwashiorkor in Kampala showed a significant increase in FIGlu excretion after a ro d course of trimethoprim, compared with a control group. Evidence of folate deficiency persisted Io d after treatment with the drug (Poskitt \& Parkin, 1972). Pyrimethamine, an antimalarial drug, similarly blocks dihydrofolate reductase and has been associated with clinical folate deficiency (Waxman $\&$ Herbert, 1969). This drug is frequently used in areas where malnutrition is common, but the home that provides regular antimalarial prophylaxis probably provides a good diet and healthy children as well. Where diet is inadequate, prolonged administration of trimethoprim or pyrimethamine without folate supplements should be avoided.

Trimethoprim also inhibits the conversion of phenylalanine to tyrosine (England \& Coles, 1972). Metabolism of phenylalanine is impaired in kwashiorkor (Whitehead, 1969) so trimethoprim given to children being treated for kwashiorkor with a high-protein diet could produce elevation of phenylalanine levels, with the possibility of brain damage in young children.

\section{Effects of other chemotherapeutic agents}

$F e$. Transferrin, the $\beta-1$ globulin that binds $F e$ in the plasma, is usually low in untreated kwashiorkor, and may be more or less fully saturated with $\mathrm{Fe}$ (Viteri, Alvarado, Luthringer \& Wood, 1968). Children with transferrin levels that remain low after the onset of dietary treatment have increased mortality, presumably due to overwhelming infection (McFarlane, Reddy, Adcock, Adeshina, Cooke \& Akene, 1970). Most centres treat malnourished children with Fe supplements (Staff, r968). It has been suggested that such supplements produce saturation of transferrin, free $\mathrm{Fe}$ in the plasma and loss of bacteriostasis, since in vitro studies show that free $\mathrm{Fe}$ encourages bacterial multiplication in plasma (Weinberg, I966). In Kampala, giving ferrous sulphate to out-patient children with kwashiorkor was not associated with a definitely lower rate of survival, but follow-up of the children was too poor to draw real conclusions (Poskitt, unpublished results). Fe in gut mucosal cells is not necessarily transferred to the plasma. It may remain bound as ferritin and may be shed into the gut lumen with the cell, a situation that probably occurs in proteindeficient rats (Viteri et al. I968). Using intramuscular $\mathrm{Fe}$-dextran complex in kwashiorkor produced no increased mortality, although plasma Fe levels probably rose rapidly (Adams, Scragg, Naidoo, Liljestrand \& Cockram, 1967). In Kampala in 1969 and 1970 , in-patients with kwashiorkor receiving oral and intramuscular $\mathrm{Fe}$ 
had a higher mortality than those given oral Fe only. However, the children receiving intramuscular $\mathrm{Fe}$ had significantly lower albumin and haemoglobin levels and appeared generally more ill (Poskitt, unpublished results). The risks of Fe therapy early in the treatment of kwashiorkor remain uncertain. There is in vitro evidence that $\mathrm{Fe}$ deficiency is associated with both decreased cell-mediated immunity (Joynson, Jacobs, Murray Walker \& Dolby, 1972) and humoral antibacterial activity (Chandra, 1973). Some children with kwashiorkor do have severe Fe-deficiency anaemia in association with hookworm infestation. Cardiac failure is most likely where the blood haemoglobin is below $70 \mathrm{~g} / 1$. Thus, denying children Fe supplements early in treatment has a doubtful effect on resistance to bacterial infection and may increase the incidence of cardiac failure, since it is in the first week of treatment that this complication occurs (Wharton et al. $x 9^{67}$ ).

Other factors. Wharton et al. (1967) showed that reducing the dietary intake of sodium greatly reduced the incidence of cardiac failure. Potassium metabolism is also important. Low total body $\mathrm{K}$ in kwashiorkor might modify the metabolism of many drugs, digoxin being a notable example.

Considering the extensive use of drugs in malnutrition, it is perhaps unfortunate that there are so few studies of drug metabolism. Many drugs have side-effects that appear to preclude their use despite therapeutic effectiveness. Nevertheless, where malnourished children are receiving effective dietary treatment and close observation in hospital, the use of drugs with adverse effects need not be avoided.

In rural clinics the situation is different. Children treated for infections, infestations, and anaemia may be living on a deficient diet and on the verge of clinical malnutrition. Their poor nutritional state may be overlooked. They receive treatment but no advice or help with their diet. These children are perhaps most at risk from drugs that upset biochemical adaptation to nutritional stress. And these children are elusive to follow-up study. It is important to establish that drug treatment is at least doing them no harm.

\section{REFERENCES}

Adams, E. B., Scragg, J. N., Naidoo, B. T., Liljestrand, S. K. \& Cockram, V. I. (1967). Br. med. $\mathcal{F}$. iii, 45 I.

Balmer, S., Howells, G. \& Wharton, B. A. (1970). Y. trop. Pediat. 16, 20.

Bayes, B. J. \& Hamilton, J. R. (1969). Archs Dis. Childh. 44, 76.

Beck, E. A. (1970). In Iron Deficiency p. 487 [L. Hallberg, H. G. Harwerth and A. Vanotti, editors]. New York: Academic Press.

Beresford, C. H., Neale, R. J. \& Brooks, O. G. (1971). Lancet i, 568.

Berman, H. A. \& Weinstein, L. (1971). Am. F. clin. Nutr. 24, 260.

Brunser, O., Reid, A., Monckeberg, F., Maccioni, A. \& Contreras, I. (Ig68). Am. F. clin. Nutr. 2 I, 976.

Chandra, R. K. (I973). Archs Dis. Childh. 48, 864.

Cohlan, S. Q., Bevelander, G. \& Tiamsic, T. (1963). Am. F. Dis. Child. ro5, 453.

Dean, R. F. A. (1965). In Recent Advances in Paediatrics 3 rd ed., p. 234 [D. Gairdner, editor]. London: J. \& A. Churchill Ltd.

England, J. M. \& Coles, M. (1972). Lancet ii, I34I.

Greenberger, N. J. (1973). Am. F. clin. Nutr. 26, 104.

Jacobsen, E. D., Chodos, R. B. \& Faloon, W. W. (1960). Am. .. Med. 28, 524.

Joliffe, N., Frontali, G., Maggioni, G., Corbo, S. \& Lanciano, O. (1956). Antibiotics A. p. rg. 
Joynson, D. H. M., Jacobs, A., Murray Walker, D. \& Dolby, A. E. (1972). Lancet ii, $105^{8}$. Lancet (1973). Lancet ii, $95^{\circ}$.

McFarlane, H., Reddy, S., Adcock, K. J., Adeshina, H., Cooke, A. R. \& Akene, J. (1970). Br. med. F. iv, 268.

Mata, L. J., Mejicanos, M. L. \& Jimenez, F. (1972). Am. F. clin. Nutr. 25, 1380.

Neuvonen, P. J., Gothoni, G., Hackman, R. \& af Bjorksten, K. (1970). Br. med. F. iv, 532.

Poskitt, E. M. E. (1972). Trans. R. Soc. trop. Med. Hyg. 66, 931.

Poskitt, E. M. E. \& Parkin, J. M. (1972). Archs Dis. Childh. 47, 626.

Staff, T. H. E. (1968). E. Afr. med. F. 45, 399.

Viteri, R. E., Alvarado, J., Luthringer, D. G. \& Wood, R. P. (1968). Vitams Horm. 26, 573.

Waterlow, J. C. (1968). Lancet ii, rogr.

Waxman, S. \& Herbert, V. (1969). New Engl. F. Med. 280, 1316.

Weinberg, E. D. (1966). Bact. Rev. 30, 136.

Weisberger, A. S. (1968). In The Interaction of Drugs and Subcellular Components in Animal Cells p. 133 [P. N. Campbell, editor]. London: J. \& A. Churchill Ltd.

Wharton, B. A., Howells, G. R. \& McCance, R. A. (1967). Lancet ii, 384 .

Wharton, B. A. \& McChesney, E. W. (1970). Y. trop. Pediat. I6, I30.

Whitehead, R. G. (1969). Proc. Nutr. Soc. 28, I. 